\title{
Frequency of ABO, Rh Blood Group Alleles Among Oromo, Amhara and Wolayita Ethnic Group Students in Robe Secondary, Preparatory and Zeybela Primary School, Bale, Ethiopia
}

\author{
Nigusu Girma ${ }^{1}$, Yohannes Petros ${ }^{2}$ \\ ${ }^{1}$ Ethiopian Biodiversity Institute, Goba Biodiversity Center, Goba, Ethiopia \\ ${ }^{2}$ Department of Biology, College of Natural and Computational Science, Haramaya University, Haramaya, Ethiopia \\ Email address: \\ yohannesn2000@gmail.com (N. Girma), yohannespetsim@gmail.com (Y. Petros)
}

\section{To cite this article:}

Nigusu Girma, Yohannes Petros. Frequency of ABO, Rh Blood Group Alleles Among Oromo, Amhara and Wolayita Ethnic Group Students in Robe Secondary, Preparatory and Zeybela Primary School, Bale, Ethiopia. International Journal of Genetics and Genomics.

Vol. 5, No. 2, 2017, pp. 19-26. doi: 10.11648/j.ijgg.20170502.11

Received: February 21, 2017; Accepted: March 13, 2017; Published: June 1, 2017

\begin{abstract}
The $\mathrm{ABO}$ and $\mathrm{Rh}$ blood groups are the most important blood groups despite the long list of several other blood groups discovered so far. The $\mathrm{ABO}$ and $\mathrm{Rh}$ blood groups varies worldwide and are not found in equal numbers even among ethnic groups. Therefore, this study aimed at having information on the frequencies of alleles, phenotypes and genotypes of $\mathrm{ABO}$ and $\mathrm{Rh} \mathrm{D}$ blood groups among the major ethnic groups of Robe Secondary and Preparatory and Zebela Primary school students in Oromia region, Bale zone, Robe town. A total of 600 students were purposively selected and divided into 3 major ethnic groups i.e., Oromo, Amahara, and Wolayita, each consists of 200 students. Purposively sampled students were obtained on the basis of their willingness to participate by filling all their profile and signed on the consent agreement format. Differences in allelic, phenotypic and genotypic frequencies of the (ABO) and $\mathrm{Rh} \mathrm{D}$ blood groups among the three ethnic groups of the students were observed. Blood group $\mathrm{O}$ and $\mathrm{Rh}$ (D) positive has highest allelic and phenotypic frequencies while blood group $\mathrm{AB}$ and $\mathrm{Rh}$ (D) negative has the lowest allelic and phenotypic frequencies in all the three ethnic groups. However, apart from the importance of $\mathrm{ABO}$ and $\mathrm{Rh}$ blood groups in blood transfusion practice, it is therefore imperative to have information on the distribution of these blood groups in any population group that comprise different ethnic groups.
\end{abstract}

Keywords: Allele, Ethnic Group, Frequency, Genotypes, Phenotypes, ABO Blood Group, Rh Blood Group

\section{Introduction}

The $\mathrm{ABO}$ and $\mathrm{Rh}$ blood groups are among the useful genetic markers in human population studies. They are the most well known and medically significant blood types in blood transfusion. The ABO system is the first polymorphism to be defined in human beings and was first describedby Karl Landsteiner in 1901 (Greenwell, 1997).

The Rhesus (Rh)D was in fact was the fourth blood group system to be discovered and latter ranked second to $\mathrm{ABO}$ system in terms of clinical importance (Ahmed etal., 2009). Both are of equal importance in clinical and forensic medicine.

The human red blood cell contains different types polysaccharide antigens called agglutinogen. The A and B antigens are important complex oligosaccharide antigens on their external surface. Antibodies are produced in the blood plasma against these A and $\mathrm{B}$ antigens and continued to be produced throughout a person's life. According to the presence of antigens and agglutinins, individuals are divided in to 4 major blood groups $\mathrm{A}, \mathrm{B}, \mathrm{AB}$ and $\mathrm{O}$ (Garratty et al., 2000).

Blood carries several antigens with in it, which form the basis of its reactivity and hence it is not possible to mix the blood of all humans without initiating an immune reaction. Only the blood samples, which share the same antigenic 
identity, do not initiate an immune response, and hence are termed as compatible. The utility of these antigens is not only for blood transfusion or organ transplantation, but have also been utilized in genetic research, anthropology and tracing of ancestral relation to human beings (Eastlund T, 1998).

The need for blood group prevalence studies is multipurpose, as besides their importance in evolution, their relation to disease and environment is being increasingly sought in modern medicine. It also plays a key role in medical treatment prior to blood transfusion and child birth. The blood group is determined by the genetic make-up of the alleles of a system.Estimates of genes frequency provide very valuable information on the genetic similarities or differences of different populations and to some extent on their ancestral genetic linkage, despite the cultural and religious differences (Meade, 1994).

Blood grouping has improved with the advent of monoclonal antibodies and the automation of testes. Although different advanced techniques, such as micro plate method, PCR based typing, FMC based typing, mini sequencing analysis, fluorescent immune micro plate technique, sandwich ELISA method, etc... are available for ABO genotyping, the Manual method has its own significance not only in blood typing but also measuring its genotypic frequency by Hardy- Weinberg law (Srikumary et al., 1987).

Classification of the blood group was based on observation of the agglutination reaction between an antigen on erythrocytes and antibodies present in the serum of individuals directed against these antigens. Where no agglutination had occurred, either the antigen or the antibody are missing from the mixture. $\mathrm{ABO}$ and $\mathrm{Rh}$ blood group systems in humans are two important genetic markers that are routinely analyzed prior to blood transfusion and medical treatment. The ABO blood group system is governed by a single gene (the $\mathrm{ABO}$ gene) with three alleles $\left(\mathrm{I}^{\mathrm{A}}, \mathrm{I}^{\mathrm{B}}\right.$ and $\left.\mathrm{I}^{\mathrm{O}}\right)$, of which ${ }^{\mathrm{A}}$, and $\mathrm{I}^{\mathrm{B}}$ alleles are co-dominant but both of them are dominant over the recessive alleles $\mathrm{I}^{\mathrm{O}}$ in intra allelic interaction in diploid condition. The gene for $\mathrm{ABO}$ blood group is located on the long arm of the ninth chromosome9q34.1 of human genome (Amundadottir etal., 2009)while that of $\mathrm{Rh}$ is located on the short arm of the first chromosome, 1p34-p36 (Cartron1994).

The ABO and Rh blood group alleles vary worldwide and are not found in equal numbers even among the same ethnic groups. Among African-Americans the distribution of $\mathrm{ABO}$ blood group is type $\mathrm{O}, 46 \%$; A, 27\%; type B, $20 \%$; and type $\mathrm{AB}, 7 \%$. AmongCaucasians in the United states, the distribution of type O, 47\%; type A, 41\%; type B, $9 \%$; and type $\mathrm{AB}, 3 \%$. Also, among Western Europeans, type O, 46\%; type A, $42 \%$; type B, $9 \%$ and type AB, 3\% (L. Beckman, 2008). Table 1 shows the distribution of the ABO blood types along racial and ethnic lines.
Table 1. Racial and ethnic distribution of $A B O$ (without Rh) blood types.

\begin{tabular}{|c|c|c|c|c|}
\hline PEOPLE GROUP & $\mathrm{O}(\%)$ & $A(\%)$ & B (\%) & $\begin{array}{l}\text { AB } \\
(\%)\end{array}$ \\
\hline Aborigines & 61 & 39 & 0 & 0 \\
\hline Abyssinians/Ethiopia & 43 & 27 & 25 & 5 \\
\hline Ainu (Japan) & 17 & 32 & 32 & 18 \\
\hline Albanians & 38 & 43 & 13 & 6 \\
\hline Grand Andamanese & 9 & 60 & 23 & 9 \\
\hline Arabs & 34 & 31 & 29 & 6 \\
\hline Armenians & 31 & 50 & 13 & 6 \\
\hline Asian (in USA - General) & 40 & 28 & 27 & 5 \\
\hline Austrians & 36 & 44 & 13 & 6 \\
\hline Bantus & 46 & 30 & 19 & 5 \\
\hline Basques & 51 & 44 & 4 & 1 \\
\hline Belgians & 47 & 42 & 8 & 3 \\
\hline Blackfoot (N. Am. Indian) & 17 & 82 & 0 & 1 \\
\hline Bororo (Brazil) & 100 & 0 & 0 & 0 \\
\hline Brazilians & 47 & 41 & 9 & 3 \\
\hline Bulgarians & 32 & 44 & 15 & 8 \\
\hline Burmese & 36 & 24 & 33 & 7 \\
\hline Buryats (Siberia) & 33 & 21 & 38 & 8 \\
\hline Bushmen & 56 & 34 & 9 & 2 \\
\hline Chinese-Canton & 46 & 23 & 25 & 6 \\
\hline Chinese-Peking & 29 & 27 & 32 & 13 \\
\hline Chuvash & 30 & 29 & 33 & 7 \\
\hline Czechs & 30 & 44 & 18 & 9 \\
\hline Danes & 41 & 44 & 11 & 4 \\
\hline Dutch & 45 & 43 & 9 & 3 \\
\hline Egyptians & 33 & 36 & 24 & 8 \\
\hline English & 47 & 42 & 9 & 3 \\
\hline Eskimos (Alaska) & 38 & 44 & 13 & 5 \\
\hline Eskimos (Greenland) & 54 & 36 & 23 & 8 \\
\hline Estonians & 34 & 36 & 23 & 8 \\
\hline Fijians & 44 & 34 & 17 & 6 \\
\hline Finns & 34 & 41 & 18 & 7 \\
\hline French & 43 & 47 & 7 & 3 \\
\hline Georgians & 46 & 37 & 12 & 4 \\
\hline Germans & 41 & 43 & 11 & 5 \\
\hline
\end{tabular}

Source: - (L. Beckman, (2008).

Table 2. ABO and Rh blood type donation showing matches between donor and recipient types.

\begin{tabular}{|c|c|c|c|c|c|c|c|c|c|}
\hline \multirow{2}{*}{$\sqrt{ }$} & & \multicolumn{8}{|c|}{ Donors } \\
\hline & & $\mathbf{O +}$ & A+ & B+ & $\mathbf{A B}+$ & O- ** & A- & B- & AB- \\
\hline \multirow{8}{*}{ Recipients } & $\mathrm{O}+$ & $\nu$ & & & & $\checkmark$ & & & \\
\hline & $\mathrm{A}+$ & $\nu$ & $\boldsymbol{V}$ & & & $\checkmark$ & $\checkmark$ & & \\
\hline & $\mathrm{B}+$ & $\nu$ & & $\checkmark$ & & $\checkmark$ & & $\nu$ & \\
\hline & $\begin{array}{l}\mathrm{AB}+ \\
*\end{array}$ & $\nu$ & $\checkmark$ & $\checkmark$ & $\checkmark$ & $\nu$ & $\checkmark$ & $\nu$ & $\checkmark$ \\
\hline & $\mathrm{O}-$ & & & & & $\checkmark$ & & & \\
\hline & A- & & & & & $\checkmark$ & $\checkmark$ & & \\
\hline & B- & & & & & $\checkmark$ & & $\checkmark$ & \\
\hline & AB- & & & & & $\checkmark$ & $\checkmark$ & $\nu$ & $\checkmark$ \\
\hline
\end{tabular}

* Type $\mathrm{AB}+$ is the universal recipient: Although those with $\mathrm{AB}$ blood type may be referred to as universal recipients, in actuality, type $A B+$ blood is that of the universal recipient, whereas type AB- is not. This is an important distinction to make.

** Because A-, $\mathrm{A}+, \mathrm{B}-, \mathrm{B}+, \mathrm{AB}-, \mathrm{AB}+, \mathrm{O}-$ and $\mathrm{O}+$ individuals can all receive blood from donors of type $\mathrm{O}$ - blood, an individual with type $\mathrm{O}$ - blood is deemed universal donor. In similar manner, $\mathrm{O}+$ is not the universal donor blood type.

As far as transfusion compatibility is concerned, it is not strictly as simple as matching $\mathrm{A}, \mathrm{B}$, and $\mathrm{O}$ groups. In other words, no individual will ever receive a blood transfusion 
based on the ABO system alone. The Rhesus factor must also be considered. Together, the Rhesus factor and ABO blood grouping are the two most important compatibility factors to consider. (Mc Clelland DBL, 2001).

African Countries like Kenya and Nigeria that have ethnically diversified people like Ethiopia carried out many researches on $\mathrm{ABO}$ and $\mathrm{Rh}$ blood group testing and came up with useful information used in different health care practices associated with blood types. But; here in Ethiopia, due to long time prevailed law that prevents research on human beings and animals because of ethical and confidential case, there was little or no such type of research and research findings in the study area and/or in the country. So, this study is significant in coming up with document that shows the phenotypic genotypic and allelic frequencies of $\mathrm{ABO}$ and $\mathrm{Rh}$ (D) blood groups that plays a key role in genetic marker of the three major ethnic groups - Oromo, Amhara and Wolayita that serves as a base line information in creating awareness as different ethnic groups living in the same geographical area necessarily who were not interbreed shows differences in their blood type frequencies and also it is usedto reduce complication occurred during blood transfusion activities and hemolytic disease of the newborn (HDN). It also used in adding knowledge to the already existing body of knowledge and serves as a reference material for another research of the same type or researches of different version of this topic carried in the zone or other places of our country.

Therefore the general objective of the study is to come up with document that shows differences on the phenotypic, genotypic and allelic frequencies of $\mathrm{ABO}$ and $\mathrm{Rh}$ blood group system among Robe Secondary and Preparatory and Zebela Primary School students belonging to the three ethnic groups living in the same geographical areawho were not interbreed.This research findings has multi-purposes future utilities for the health planners and also shows the common trends of the prevalence of various blood groups among the three ethnic group students.

Specific Objectives

a. To determine the frequency distribution of $\mathrm{ABO}$ and $\mathrm{Rh}$ blood group phenotypes among the Oromo, Amhara and Wolayita students of Robe Secondary and preparatory and Zebela primary school and compare it with the distribution of blood group phenotypes of the country, Ethiopia.

b. To determine the genotypic and allelic frequencies of $\mathrm{ABO}$ and $\mathrm{Rh}$ blood groups among the three ethnic groups under study.

\section{Materials and Methods}

\subsection{Description of the Study Area}

The study was conducted in Oromia regional state, Bale zone, Robe town (Robe Secondary and Preparatory and Zebela Primary School which have got over 2752 students belonging to different ethnic groups. The town is located at an altitude of 2492 meter above sea level and $430 \mathrm{Km}$ to the southeast of Addis Ababa the capital city of Ethiopia, having an average annual rain fall of $1400 \mathrm{~mm}$. According to 2007 G.C. National house and population census report, Robe town has a total population of 57,385 from which 29,148 is male and 28,237 is female (Projected by the annual growth rate of $2.93 \%$ (CSAE, 2007).

\subsection{Sampling Procedure and Sample Size}

Robe Secondary and Preparatory School and Zebela Primary School have 2752 students of which Robe Secondary and Preparatory school comprises of 1237 students while the later 1515 students enrolled for the academic year 2012/2013 G.C. The latter school was included in the research activity to increase the chance of getting students' of Amhara and Wolayita ethnic groups due to the fact that this school is the only primary school that uses Amharic language for media of education and hence the majority of Amhara and Wolayita ethnic group children attend their primary education in here. The study was conducted on 600 purposively sampled students comprising approximately $22 \%$ of the students' population within the two schools. The sample students were selected purposively so as to include equal number of students from the three ethnic groups:- Oromo, Amhara and Wolayita in the two schools. Thus, the sampled students were divided in to three equal groups each consisting of 200 students and stratified along ethnic lines. Purposively sampled students were obtained on the basis of their willingness to participate by filling all their profile and signed on the consent agreement format. The profile filled by the participant students were got acceptance by the researcher after the two school directors signed and stamped for its correctness. The information about ethnic groups was reapproved by directly asking the students during his or her actual participation. Students from parents of two different ethnic groups were not included in the research activity due to the difficulty in determining the ethnic group of such individuals.

\subsection{Blood Sample Collection and Grouping Method}

The ABO and Rh blood group test was performed by using standardized and packed lancet, to obtain blood from finger picks for each sample students. Blood samples were taken from finger picks, and open slide method of testing for $\mathrm{ABO}$ and Rh (D) blood groups was followed (Bhasin et al., 1995). Then, it was placed on a clean slide in three places anda drop of one of the Anti sera that is antibody coated, Anti-A, Anti-B and Anti-D was added to each of an individual's blood samples and mixed using a glass rod. Standardized anti sera, Anti-A, Anti-B and Anti-D were obtained commercially from Robdan medical drugs and chemicals distributor in RobeBale.Blood groups and Rhesus factor were determined on the basis of agglutination, and recorded as blood group $\mathrm{A}^{+}, \mathrm{B}^{+}$, $\mathrm{AB}^{+}$, and $\mathrm{O}^{+}$and $\mathrm{A}^{-}, \mathrm{B}^{-}, \mathrm{AB}^{-}$, and $\mathrm{O}^{-}$. The blood samples were collected and tested by qualified laboratory technicians using the standard clinical procedure.

\subsection{Method of Data Analysis}

The genetic structure of a population was determined by 
the total number of all alleles (the gene pool) in the case of sexually interbreeding individuals; the structure was also characterized by the distribution of alleles in to genotypes. The genetic structure could be described in terms of allelic and genotypic frequencies (Russel, 2005). For this study, the frequency of the blood group genotypes was used to calculate the frequency of the ABO blood group alleles by using the extension of Hardy-Weinberg principle (HWP), and chisquare $\left(\chi^{2}\right)$ test was used during comparison of observed frequencies of $\mathrm{ABO}$ and $\mathrm{Rh}$ blood group with expected frequencies. (Chakraborty DP, 2010). Extension of the Hardy Weinberg law to loci with more than two alleles was used to analyze the genotypic and allelic frequencies based on Hardy-Weinberg equations. Chi-square goodness- of-fit statistic was calculated to compare observed and expected frequencies and to investigate heterogeneity.

When two alleles are present at a loci, the Hardy Weinberg law tells us at equilibrium the frequencies of the genotype is:$\mathrm{p}^{2}+2 \mathrm{pq}+\mathrm{q}^{2}=1$, which is the square of allelic frequencies $(\mathrm{p}$ $+\mathrm{q})^{2}$

This is the simple binomial expansion, and this principle of probability theory can be extended to any number of alleles that are sampled two at a time in to a diploid zygote (Daniel et al., 2007).For this study three alleles are computed (A, B and $\mathrm{O}$ ), with frequencies equal to $\mathrm{p}, \mathrm{q}$ and $\mathrm{r}$ respectively. The frequencies of the genotype at equilibrium will be computed by the square of thee allelic frequencies.

$$
\begin{gathered}
(\mathrm{p}+\mathrm{q}+\mathrm{r})^{2}=\mathrm{p}^{2}(\mathrm{AA})+2 \mathrm{pq}(\mathrm{AB})+\mathrm{q}^{2}(\mathrm{BB})+2 \mathrm{pr}(\mathrm{AO})+2 \mathrm{qr} \\
(\mathrm{BO})+\mathrm{r}^{2}(\mathrm{OO})=1
\end{gathered}
$$

(Griffith et al., 2008).

Gene frequency is calculated considering two alleles at the same locus for Rh system and three alleles at the same locus for $\mathrm{ABO}$ system using standard formulae of quantitative genetics. ABO allele frequencies were estimated according to a published method which yields results that are close to maximum likelihood estimates. Preliminary estimates were calculated as:

$$
p=1-\sqrt{ } B+O, q=1-\sqrt{ } A+O, r=\sqrt{ } O
$$

where $\mathrm{p}, \mathrm{q}, \mathrm{r}$ denote allele frequencies and $\mathrm{A}, \mathrm{B}, \mathrm{O}$ denote observed frequencies of blood groups A, B and O. A correction factor (d) will be calculated according to:-

$$
\mathrm{d}=1-\mathrm{p}-\mathrm{q}-\mathrm{r}
$$

The final allele frequencies were then calculated as follows:-

$$
\mathrm{p} 1=\mathrm{p}(1+\mathrm{d} / 2) ; \mathrm{q} 1=\mathrm{q}(1+\mathrm{d} / 2) ; \mathrm{r} 1=(\mathrm{r}+\mathrm{d} / 2)(1+\mathrm{d} / 2)
$$

where $\mathrm{p} 1, \mathrm{q} 1$, and $\mathrm{r} 1$ denote corrected allele frequencies. Rh (D) allele frequencies were calculated according to the Hardy-Weinberg equation. Observed and expected genotype frequencies in Hardy-Weinberg were calculated on the basis of gene's frequency and Chi-square tests was done to test the independence and the goodness of fit for genotype frequencies (Chakraborty, 2010).

The Chi-square $\left(\chi^{2}\right)$ test statistic is then

$$
x^{2}=\sum \frac{\left(O_{i}-E_{i}\right)^{2}}{E_{i}}
$$

Ethical clearance of the study design was obtained from Bale zone Health Office after it was revised and got acceptance by the health management committee of the office.

\section{Results, Discussions and Conclusion}

\subsection{Phenotypic Frequencies of $A B O$ and Rh Blood Group Among Oromo, Amhara and Wolayita Ethnic Groups in the Study Area}

Table 3 represents the phenotypic percentage distribution of $\mathrm{ABO}$ and $\mathrm{Rh}$ blood group of Oromo, Amhara and Wolayita ethnic group students in Robe secondary and preparatory and Zebela Primary school of 200 blood samples tested from each ethnic groups in this study are O (42\%), A (28\%), B (25\%) and AB (10\%) for Oromo ethnic group, O (43\%), A (29\%), B $(23 \%)$ and $\mathrm{AB}(10 \%)$ for Amhara ethnic group and $\mathrm{O}(44.5 \%)$, A (27\%), B (24\%) and AB (4.5\%) for Wolayita ethnic group.

With respect to Rhesus $93.5 \%$ of the population sampled

\begin{tabular}{|c|c|c|c|c|c|c|c|}
\hline \multirow{2}{*}{ Study Group } & \multicolumn{5}{|c|}{ ABO Blood Grouping System } & \multicolumn{2}{|c|}{ Rh (Rhesus Blood Grouping System } \\
\hline & $\mathbf{O}$ & $\mathbf{A}$ & $\mathbf{B}$ & $\mathbf{A B}$ & Total & $\mathbf{R h}+$ & Rh- \\
\hline Oromo & $\begin{array}{l}84 \\
(42)\end{array}$ & $\begin{array}{l}56 \\
(28)\end{array}$ & $\begin{array}{l}50 \\
(25)\end{array}$ & $\begin{array}{l}10 \\
(5)\end{array}$ & 200 & $\begin{array}{l}187 \\
(93.5)\end{array}$ & $\begin{array}{l}13 \\
(6.5)\end{array}$ \\
\hline Amhara & $\begin{array}{l}86 \\
(43)\end{array}$ & $\begin{array}{l}58 \\
(29)\end{array}$ & $\begin{array}{l}46 \\
(23)\end{array}$ & $\begin{array}{l}10 \\
(5)\end{array}$ & 200 & $\begin{array}{l}189 \\
(94.5)\end{array}$ & $\begin{array}{l}11 \\
(5.5)\end{array}$ \\
\hline Wolayita & $\begin{array}{l}89 \\
(44.5)\end{array}$ & $\begin{array}{l}54 \\
(27)\end{array}$ & $\begin{array}{l}48 \\
(24)\end{array}$ & $\begin{array}{l}9 \\
(4.5)\end{array}$ & 200 & $\begin{array}{l}189 \\
(94.5)\end{array}$ & $\begin{array}{l}11 \\
(5.5)\end{array}$ \\
\hline Over all & $\begin{array}{l}259 \\
(43.17)\end{array}$ & $\begin{array}{l}168 \\
(28)\end{array}$ & $\begin{array}{l}144 \\
(24)\end{array}$ & $\begin{array}{l}32 \\
(4.83)\end{array}$ & 600 & $\begin{array}{l}565 \\
(94.17)\end{array}$ & $\begin{array}{l}35 \\
(5.83)\end{array}$ \\
\hline
\end{tabular}
from Oromo ethnic group were Rh (D) +vewhile 6.5\% were Rh (D)-ve and $94.5 \%$ population sampled from both Amhara and Wolayita ethnic groups were Rh (D) +ve while 5.5\% were $\mathrm{Rh}(\mathrm{D})$-ve.

Table 2. Phenotypic Distribution of ABO and Rh Blood Group Systems among the three ethnic groups (Oromo, Amhara and Wolayita).

Values in parentheses represent phenotype percentage occurrence

Source: Own survey data, 2013 


\subsection{Estimating Genotypic and Allelic Frequencies of $A B O$ and Rh Blood Group Among Oromo, Amhara and Wolayita Ethnic Groups in the Study Area}

Table 4 represents the allelic and genotypic frequencies of $\mathrm{ABO}$ and Rh blood group of Oromo, Amhara and Wolayita ethnic group students in Robe secondary and preparatory and Zebela Primary school. The allelic frequencies of ABO blood group for Oromo ethnic group was $\mathrm{O}=0.6540, \mathrm{~A}=0.1821$ and $\mathrm{B}$ was 0.1639 . The allelic frequencies of $\mathrm{ABO}$ blood group for the Amhara ethnic group was also $\mathrm{O}=0.6600, \mathrm{~A}=$ 0.1881 and $\mathrm{B}$ was 0.1519 . Similarly $\mathrm{O}=0.6772, \mathrm{~A}=0.1729$ and B was 0.1549 for Wolayita ethnic groups.

With respect to Rhesus blood grouping system, the allelic frequency of Oromo ethnic group was 0.745 for D and 0.255 for $\mathrm{d}$. And the allelic frequency was found to be 0.765 for $\mathrm{D}$ and 0.235 for $\mathrm{d}$ for both Amhara and Wolayita ethnic groups.

Table 4 also shows the frequencies of the various genotypes in the $\mathrm{ABO}$ and $\mathrm{Rh}$ systems. So that $\mathrm{OO}=$ $0.4277, \mathrm{AA}=0.0332, \mathrm{AO}=0.2382, \mathrm{AB}=0.0597, \mathrm{BB}=$ 0.0269 and $\mathrm{BO}=0.2144$ in Oromo ethnic group. It follows the same patterns of distribution in both Amhara and Wolayita ethnic groups. The frequency of the genotypes for $\mathrm{Rh}$ blood group in Oromo ethnic group were 0.5550 for DD, 0.380 for Dd and 0.065 for dd and 0.5852 for DD, 0.3596 for Dd and 0.0552 for dd both for Amhara and Wolayita ethnic groups.

Table 4. Allelic and Genotypic frequencies of $A B O$ and Rh blood group for the three ethnic groups (Oromo, Amhara and Wolayita).

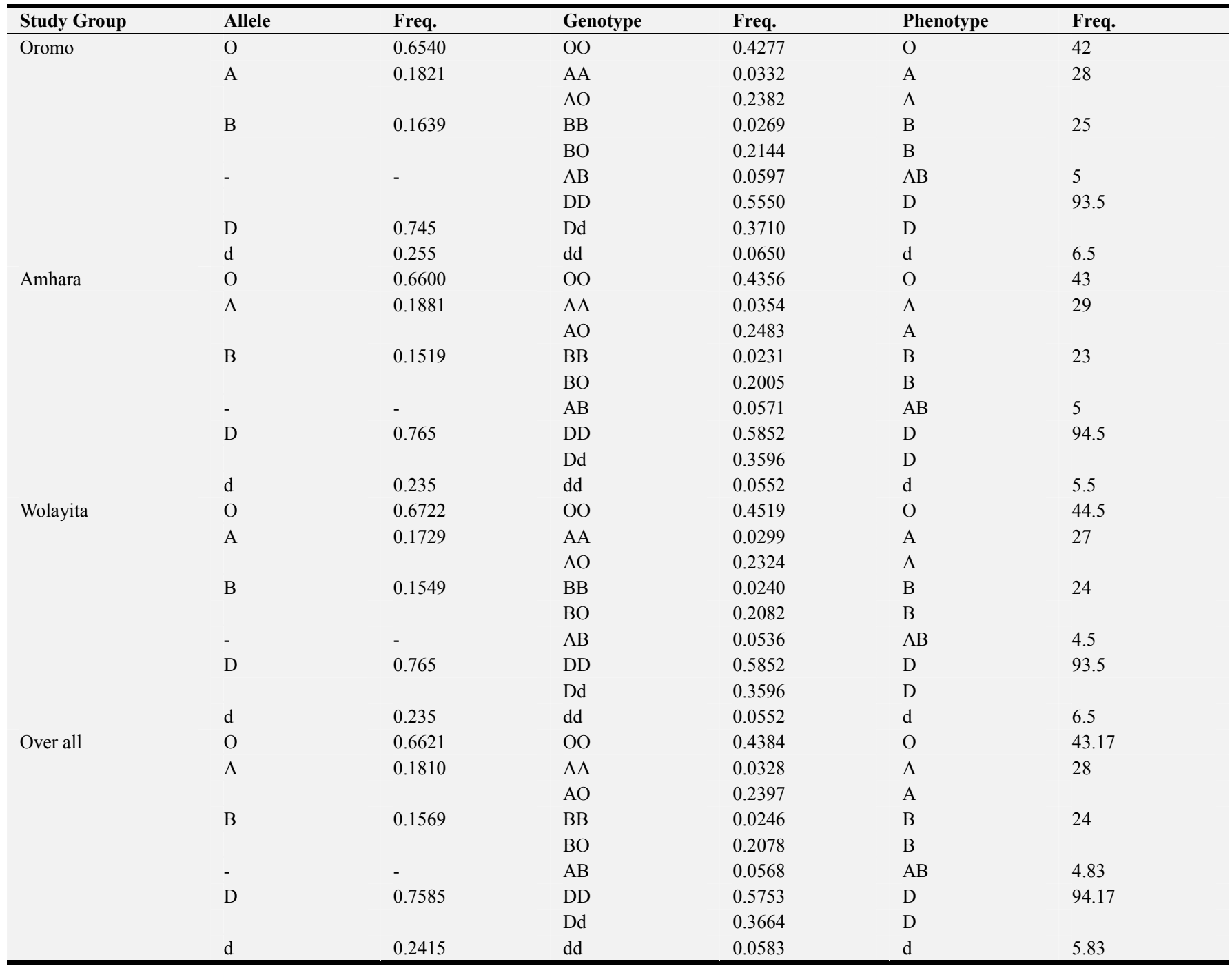

Source: Own survey data, 2013

\subsection{Statistical Method to Test the Goodness-of-Fit}

Table 5 represents the observed proportions of $\mathrm{ABO}$ and $\mathrm{Rh}$ individuals in the studied population when compared with expected proportions. It also shows the chi-square $\left(\chi^{2}\right)$ and probability $(p)$ value for all the three ethnic groups separately and for the overall student population sampled in the study. 
Table 5. Observed versus expected frequency of $A B O$ and Rh Blood groups among individuals sampled from the three ethnic groups (Oromo, Amhara and Wolayita).

\begin{tabular}{|c|c|c|c|c|c|c|c|c|c|c|}
\hline \multirow{2}{*}{$\begin{array}{l}\text { StudyGr } \\
\text { oup }\end{array}$} & \multicolumn{5}{|c|}{ ABO Blood system } & \multicolumn{5}{|c|}{ Rh Blood System } \\
\hline & Blood group & Obs. No & $\begin{array}{l}\text { Obs. Freq. } \\
(\%)\end{array}$ & $\begin{array}{l}\text { Exp. } \\
\text { Freq(\%) }\end{array}$ & Exp. No & Blood Group & $\begin{array}{l}\text { Obs. } \\
\text { No }\end{array}$ & $\begin{array}{l}\text { Obs. Freq. } \\
(\%)\end{array}$ & $\begin{array}{l}\text { Exp. } \\
\text { Freq.(\%) }\end{array}$ & Exp. No \\
\hline \multirow{4}{*}{ Oromo } & $\mathrm{O}$ & 84 & 42 & 0.4356 & 85.54 & $\mathrm{Rh}(\mathrm{D})$ & 187 & 0.745 & 0.9350 & 186.995 \\
\hline & $\mathrm{A}$ & 56 & 28 & 0.2713 & 54.28 & $\operatorname{Rh}(d)$ & 13 & 0.255 & 0.0650 & 13.005 \\
\hline & $\mathrm{B}$ & 50 & 25 & 0.2413 & 48.26 & & & & & \\
\hline & $\mathrm{AB}$ & 10 & 5 & 0.0579 & 11.94 & & & & & \\
\hline \multicolumn{11}{|c|}{$\chi^{2}=0.4601, p<0.95$} \\
\hline \multirow{4}{*}{ Amhara } & $\mathrm{O}$ & 86 & 43 & 0.4356 & 87.12 & $\mathrm{Rh}(\mathrm{D})$ & 189 & 0.765 & 0.9448 & 188.96 \\
\hline & A & 58 & 29 & 0.2837 & 56.74 & $\mathrm{Rh}(\mathrm{d})$ & 11 & 0.235 & 0.0552 & 11.04 \\
\hline & $\mathrm{B}$ & 46 & 23 & 0.2236 & 44.72 & & & & & \\
\hline & $\mathrm{AB}$ & 10 & 5 & 0.0571 & 11.43 & & & & & \\
\hline \multicolumn{11}{|c|}{$\chi^{2}=0.2556, p>0.95$} \\
\hline \multirow{4}{*}{ Wolayita } & $\mathrm{O}$ & 89 & 44.5 & 0.4519 & 90.38 & $\mathrm{Rh}(\mathrm{D})$ & 189 & 0.765 & 0.9448 & 188.96 \\
\hline & A & 54 & 27 & 0.2623 & 52.46 & $\mathrm{Rh}(\mathrm{d})$ & 11 & 0.235 & 0.0552 & 11.04 \\
\hline & $\mathrm{B}$ & 48 & 24 & 0.2322 & 46.45 & & & & & \\
\hline & $\mathrm{AB}$ & 9 & 4.5 & 0.0536 & 10.72 & & & & & \\
\hline \multicolumn{11}{|c|}{$\chi^{2}=0.3965, p \leq 0.95$} \\
\hline \multirow{4}{*}{ Overall } & $\mathrm{O}$ & 259 & 43.17 & 0.4384 & 263.04 & $\mathrm{Rh}(\mathrm{D})$ & 565 & 0.7585 & 0.9417 & 565.02 \\
\hline & A & 168 & 28 & 0.2725 & 163.50 & $\mathrm{Rh}(\mathrm{d})$ & 35 & 0.2415 & 0.0583 & 34.98 \\
\hline & $\mathrm{B}$ & 144 & 24 & 0.2324 & 139.44 & & & & & \\
\hline & $\mathrm{AB}$ & 29 & 4.83 & 0.0568 & 34.08 & & & & & \\
\hline \multicolumn{11}{|c|}{$\chi^{2}=1.082, p \leq 0.8$} \\
\hline
\end{tabular}

Source:- Own survey data, 2013

\subsection{Discussions}

As it is indicated in Table 3, the phenotypic distribution of $\mathrm{ABO}$ and Rh (D) blood group among Oromo, Amhara and Wolayita ethnic group students in Robe secondary and preparatory and Zebela primary school in Bale zone, Ethiopia. My data revealed that the ABO blood group frequencies in Oromo ethnic group was found in the order $\mathrm{O}>\mathrm{A}>\mathrm{B}>\mathrm{AB}(42 \%, 28 \%, 25 \%$ and $5 \%)$ respectively among 200 students purposively sampled. The order of ABO blood group frequencies observed in Oromo ethnic group holds true for both Amhara and Wolayita ethnic groups in which $\mathrm{O}>\mathrm{A}>\mathrm{B}>\mathrm{AB}$ and their frequencies were $43 \%, 29 \%$, $23 \%, 5 \%$ and $44.5 \%, 27 \%, 24 \%$ and $4.5 \%$ respectively among 200 students purposively sampled for each ethnic groups. When compared with other reports from similar studies, the researcher's data is consistent with previous findings from other parts of the world including Ethiopia: - $\mathrm{O}$ $(43 \%)>\mathrm{A}(27 \%)>\mathrm{B}(25 \%)>\mathrm{AB}(5 \%)$ (L. Beckman, 2008).

For example, inBritain, the percentage frequencies of the ABO bloodgroup were $47 \%, 42 \%, 9 \%$, and $3.0 \%$ for $\mathrm{O}, \mathrm{A}, \mathrm{B}$, and AB blood groups respectively (L. Beckman, 2008). Findings reported from India (USA-General) also showed that the percentage frequencies are $79 \%, 16 \%, 4 \%$, and $1 \%$ for $\mathrm{O}, \mathrm{A}, \mathrm{B}$, and $\mathrm{AB}$ blood groups respectively (L. Beckman, 2008). See Table 1. In the Northern part of Nigeria, (Kulkarni et al., 1985) obtained frequencies of $46.6 \%, 29.95 \%, 23.05 \%$ and $4.4 \%$ for blood group $\mathrm{O}, \mathrm{A}, \mathrm{B}$ and $\mathrm{AB}$ respectively and frequencies of $55.3 \%, 25.3 \%, 16.7 \%$ and $2.7 \%$ in the order $\mathrm{O}>\mathrm{A}>\mathrm{B}>\mathrm{AB}$ were also obtained among 150 students of Cell Biology and Genetics at the University of Lagos, Nigeria (Adeyemo and Soboyejo, 2006). Among the
Caucasians in the United States of America, the frequency of blood group $\mathrm{O}, \mathrm{A}$, and $\mathrm{AB}$ are $47 \%, 41 \%, 9 \%$ and $3 \%$ respectively (L. Beckman, 2008).

However; my findings seem to deviate from the results obtained by L. Beckman, 2008 on the phenotypic frequencies of blood group antigens from Ainu (Japan) where ABO blood group frequency occurredin the order $\mathrm{A}=\mathrm{B}(32 \%)>\mathrm{AB}$ $(18 \%)>\mathrm{O}(17 \%)$. It also seem not to agree with the results obtained from Swat district in Pakistan where the percentage frequencies were $\mathrm{A}=27.92 \%, \mathrm{~B}=32.40 \%, \mathrm{O}=29.10 \%$ and $\mathrm{AB}=10.58 \%$ in which $\mathrm{B}>\mathrm{O}>\mathrm{A}>\mathrm{AB}$ (Khattak et al., 2008). It is also not consistent with $\mathrm{ABO}$ phenotypic frequency of Bororo (Brazil) in which $100 \%$ of the population are O blood groups (L. Beckman, (2008).

Results shows along ethnic line, $93.3 \%$ of the oromo ethnic group (consisting 55.5\% of DD individuals and $37.995 \%$ Dd individuals) were phenotypically $\mathrm{Rh}+\mathrm{ve}$ while $6.5 \%$ were $\mathrm{Rh}-\mathrm{ve}$. In the case of Amhara and Wolayita ethnic groups $94.5 \%$ (consisting $58.5 \%$ of DD individuals and $35.96 \% \mathrm{Dd}$ individuals) were phenotypically $\mathrm{Rh}+\mathrm{ve}$ while only $5.5 \%$ were $\mathrm{Rh}-\mathrm{ve}$. These findings show that in all the three ethnic groups- Oromo, Amhara and Wolayita, the proportion of $\mathrm{Rh}$-ve is far lower than for $\mathrm{Rh}+\mathrm{ve}$. The findings are consistent with reports from previous similar studies among different sets of Nigerian population where the $\mathrm{Rh}(\mathrm{D})$ positive was found to behigher in the population sampled than the $\mathrm{Rh}$ (D)negative (Kulkarni et al., 1985,Ahmed and Obi, 1998;Omotade et al., 1999; Ahmed et al., 2004;Ahmed et al., 2007; Jeremiah and Odumody,2005, Bakare et al., 2006, Akhigbe et al., 2009, Adeyemo and Soboyejo, 2006) see Table 3.The results, however; differ from the work reported by Yousaf and colleagues where the 
population sampled among Bahawalpur division of Pakistan population were all Rh D positive (Yousaf et al., 1988). It also disagrees to that of Salmon et al. 1988 and Njoku et al., 1996 who reported rhesus positive values of $100 \%$ for Eastern Highlands of Papua Guinea and Nigeria, respectively. In addition it is dissimilar to that in Indians with a preponderance of the $\mathrm{Rh}(\mathrm{d})$ of $89.7 \%$ over the $\mathrm{Rh}(\mathrm{D})$ gene of $10.3 \%$ (Thangaraj et al., 1992).

The frequencies of the various genotypes of the $\mathrm{ABO}$ and $\mathrm{Rh}$ systems in Table 4 shows that $\mathrm{OO}=0.4277, \mathrm{AA}=0.0332$, $\mathrm{AO}=0.2382, \mathrm{AB}=0.0597, \mathrm{BB}=0.0269$ and $\mathrm{BO}=0.2144$ in Oromo ethnic group. It follows the same patterns of distribution in both Amhara and Wolayita ethnic groups. Blood group A and B shows co-dominance to each other and dominant to O. For example, in Amhara ethnic group, the frequency of AA genotype was 0.0354 while AO genotype was 0.2483 . Thus, among those who are blood group A, $13.17 \%$ were homozygous AA, while about $86.83 \%$ were heterozygous AO. Similar deduction can be made for blood group $\mathrm{B}$ and for $\mathrm{Rh}+\mathrm{ve}$ among DD and Dd individuals in all the three ethnic groups.

The frequency of the genotypes for Rh blood group were 0.5550 for $\mathrm{DD}, 0.380$ for $\mathrm{Dd}$ and 0.065 for $\mathrm{dd}$ in Oromo ethnic group and 0.5852 for DD, 0.3596 for Dd and 0.0552 for dd both for Amhara and Wolayita ethnic groups.

Hence, it is possible to say that the highest percentage of blood group A and B are found in heterozygous genotypes $\mathrm{AO}$ and $\mathrm{BO}$. Blood group $\mathrm{O}$ and homozygous dominant $\mathrm{Rh}(\mathrm{D})$ records the highest frequencies while the co dominant blood group $\mathrm{AB}$ and homozygous recessive $\mathrm{Rh}(\mathrm{d})$ genotypes record the least genotype frequencies in all the three ethnic groups under this study.

Once again as it is indicated in Table 4 in all the three ethnic group students (Oromo, Amhara and Wolayita), the allelic frequencies of $\mathrm{ABO}$ blood group was occurred in the order $\mathrm{O}>\mathrm{A}>\mathrm{B}$. It shows similar patterns of allelic frequencies with those documented from earlier studies among various segments of the world population including Ethiopia in which $\mathrm{O}(0.66)>\mathrm{A}(0.1759)>\mathrm{B}(0.1638)$. For instance similar study by Bakare et al, 2006 in Ogbomoso,South-west Nigeria,Omotade et al, 1999 among a healthy infant populationin Ibadan, Nigeria, Yan et al, 2005 on Chinesepopulations and Hussain et al, 2001 amongBalochistan in Pakistan all found the allelic frequenciesto occur in $\mathrm{O}>\mathrm{A}>\mathrm{B}$ order.

With respect to Rhesus factor, allele D is far higher in frequency than allele $d$ in all the three ethnic groups and in the overall student population sampled.

As it is indicated in table 5, the application of extended Hardy-Weinberg principle for three or more alleles yields little variation in the observed and expected genotypic frequencies and numbers which serves as a base in determining the chi-square $\left(\chi^{2}\right)$ values that further used in determining the goodness-of- fitness. Hence, the chi-square value for Oromo ethnic group is 0.4601 with $\mathrm{p} \leq 0.95$, for Amhara ethnic group $\chi^{2}=0.2556$ with $\mathrm{p}>0.95$, for Wolayita ethnic group $\chi^{2}=0.3965$ with $p \leq 0.95$ and for the overall student population sampled, the chi-square value is 1.082 with $\mathrm{p} \leq 0.8$ values. With determined degree of freedom 3 and 0.05 significance level the researcher's result is acceptable.

\subsection{Conclusion}

In this study, the percentage frequency distribution of blood group $\mathrm{O}$ is the highest with percentage frequency of $42 \%, 43 \%$ and $44.5 \%$ in Oromo, Amhara and Wolayita ethnic groups respectively, followed by blood group A $(28 \%, 29 \%$ and $27 \%)$ and blood group B (24\%, 23\% and $24 \%)$, and the least percentage frequency is that of blood group $\mathrm{AB}(5 \%$, $5 \%$ and $4.5 \%$ ) in the three ethnic groups. Moreover, this study further confirmed that Rh (D) positive has the highest percentage frequency while Rh-negative has the lowest percentage frequency as observed among the three ethnic groups. There is also a similar trend in overall student population sampled in which blood group $\mathrm{O}(43.17 \%)>\mathrm{A}$ $(28 \%)>\mathrm{B}(24 \%)>\mathrm{AB}(4.83 \%)$ and $\mathrm{Rh}(\mathrm{D}) 94.17 \%$ is by far greater than $\mathrm{Rh}(\mathrm{d})$ which scores $5.83 \%$. With respect to allelic frequencies, allele $\mathrm{O}$ records the highest frequencies $(0.6540,0.66$ and 0.6722$)$ in Oromo, Amhara and Wolayita ethnic groups respectively. Followed by allele A (0.1821, 0.1881 and 0.1729 ) while allele $B$ records the least frequencies $(0.1639,0.1519$ and 0.1549$)$. In the case of Rhesus factor allele D has a frequency distribution far higher than d allele in all the three ethnic groups under this study.

The implication of this finding is that blood type $\mathrm{O}$ is the most readily available blood group in the study area which is more advantageous for the population in the event of blood transfusion. The higher proportion of blood group $\mathrm{O}$ in the studied population is an advantage because some parts of Bale zone is a malaria epidemic zone hence individuals belonging to blood group $\mathrm{O}$ may be protected from severe malaria attack due to the mechanism of reduced resetting.

The dominance of $\mathrm{O}$ allele may be as a result of the fact that many As and Bs blood group have been heterozygous carrying $\mathrm{O}$ allele silently thereby maintaining $\mathrm{O}$ allele in the heterozygous population. For example, this finding shows that in Amhara ethnic group, the frequency of AA genotype was 0.0356 while AO genotype was 0.2483 . Thus, among those who are blood group A, $13.17 \%$ were homozygous AA, while about $86.83 \%$ were heterozygous AO. Similar deduction can be made for $\mathrm{O}$ allele to be carried silently in BO heterozygous form in blood group B in all the three ethnic groups. However; it is the researcher's candid opinion that molecular characterization of $\mathrm{O}$ allele could assist in elucidating the possible causes of blood group $\mathrm{O}$ predominance in various populations.

To sum up results from this study show the phenotypic, genotypic and allelic frequencies of $\mathrm{ABO}$ and $\mathrm{Rh}$ blood group varies in different ethnic groups and hence, it serves as a key genetic markers in population studies. I have by these results presented in this study, provide information on the Phenotypic, genotypic and allelic frequencies of $\mathrm{ABO}$ and $\mathrm{Rh}$ blood group in Oromo, Amhara and Wolayita ethnic groups, Bale zone of Ethiopia hoping that it will serve as a reference 
for other studies. I believed this study will further contribute to existing knowledge in this field and help in planning for future clinical challenges especially when it relates to blood transfusion, genetic counseling and HDN.

\section{References}

[1] Adeyemo, A. F and O. B, Soboyejo., 2006. Frequency distribution of $\mathrm{ABO}, \mathrm{RH}$ blood groups and blood genotypes among the biology and genetics students of university of Lagos, Nigeria Afri J of biotechnol 5 (22). 2062-2065.

[2] Ahmed, S. G., U. A. Ibrahim and A. W. Hassan (2007). Adequacy and pattern of blood donations in northeast Nigeria: The implications for blood safety. Ann. Trop. Med. Parasitol., 101: 725-731. PMID: 18028734.

[3] Ahmed, S. G. and S. O. Obi (1998). The incidence of ABO and rhesus-D blood groups in northeast Nigeria. Nig. J. Med., 7: $68-70$.

[4] Ahmed, S. G., B. A. Umar, A. T. Saidu and B. Jolayemi (2004). Pattern and clinical significance of ABO and rhesus-D red cell phenotypes among blood donors Birnin kudu,Nigeria. Borno. med. J., 1: 1-6.

[5] Akhigbe, R. E., S. F. Ige, A. O. Afolabi, O. M. Azeez, G. J. Adegunlola and J. O. Bamidele (2009). Prevalence of haemoglobin variants $\mathrm{ABO}$ and rhesus blood groups in Ladoke Akintola University of Technology, Ogbomoso, Nigeria. Trends Med. Res., 4: 24-29. DOI: 10.3923/tmr.2009.24.29.

[6] Amundadottir L,Kraft P, Stolzenberg-Solomon RZ, Fuchs CS, Petersen GM, Arslan A. A etal. (2009). Genome-Wide association studies identifies variants in the $\mathrm{ABO}$ locus associated with susuceptibility to pancreatic cancer. Nature Genetics. 2009; 41(9):986-90.

[7] Bakare A. A., M. A. Azeez., and J. O Agbolade., 2006 Gene frequencies of $\mathrm{ABO}$ and rhesus blood groups and haemoglobin Variants in Ogbomosho. South -West Nigeria. Afr. J. Biotechnology., 5:224-229.

[8] Bhasin MK, Chahal SMS 1995. A Laboratory Manual for Human Blood Analysis.Delhi: Kamla-RajEnterperises.

[9] Cartron,J. P. (1994). Defining the Rh blood group antigens. Biochemistry and molecular genet.cs. Blood Rev., 8:199-212.

[10] Chakraborty DP, Prediction accuracy of a sample size estimation method for ROC Students, Academic Radiology, diol:10.1016fj.acra 2010.01.007.

[11] CSAE, 2007 Population and housing census Atlas of Ethiopia.

[12] Daniel, H, L, and A. G, clark, 2007. Principle of population Genetics. $4^{\text {th }}$. Sinauer. Associates. Sunderland, Massachusetts. P633.

[13] Eastlund, T., The histo-blood groupsystem ABO and tissue transplantation. Transfusion 1998; 38: 975-988.
[14] Garratty, G., W.Dzink., PD. Issitt., DM., Lublin Reid., and T. Zelinski,. Terminology for blood group antigens and geneshistorical origins and guideline in the new millennium. Transfusion 2000; 40: 477-489.

[15] Greenwell, P.(1997): Blood group antigens: Molecules seeking a function. Glycoconjugate J. 14: 159-173.

[16] Griffiths, A. F, S. R, Wessler, R. C, Leewontin, and S. B. Carroll., 2008. Introduction to Genetic Analysis. $9^{\text {th }}$ edition. W. H. freeman and company. New York. P838.

[17] Hussain A, Shiekh SA, Haider M, Rasheed T, Malik MR. Frequency of $\mathrm{ABO}$ and $\mathrm{Rh}$ blood groups in population of Balouchistan (Pakistan). PakArmed ForcesMed J 2001;51:226.

[18] Khattak, I. D., T. M. Khan., P. Syed., A. M. Shah., S. T. Khattak., and A. Ali., (2008). Frequency of $A B O$ and rhesus blood group in swat, Pakistan $j$ Ayub Med Coll Abbottabad 2008;20(4).

[19] Kulkarni, A. G., B. Peter, R. Ibazebo, B. Dash and A. F. Fleming, (1985). The ABO and Rhesus groups in the North of Nigeria. Ann. Trop. Med. Parasitol., 79: 83-88.

[20] L. Beckman, (2008). A contribution to a physical Anthropology and population genetics: Racial and Ethine Distribution of ABO blood types, Blood Book.com.

[21] (Mc Clelland DBL. Hand book of transfusion medicine, 3rded.The stationery office, London, 2001).

[22] Meade, T. W., J. A. Cooper, Y. Stirling, D, J. Howarth, V. Ruddock, \$ G. J. Miller 1994. Factor VIII. ABO blood group and the incidence of ischemic heart disease. $\mathrm{Br} \mathrm{J}$ Haemat. 88:601-7.

[23] Njoku OU, IC Ononogbu, EO Alumunan, I Nwanjoh (1996). Serum lipids, ABO blood group and sickle cell trait. Ind. J. Physiol. Pharmacol. 40(2): 171 - 174.

[24] Omotade, O. O., A. A. Adeyemo., C. M. Kayode., S. L. falade., and S. Ikpeme, 1999. Gene frequencies of $A B O$ and $R h$ (D) blood group alleles in a healthy infect population in Ibadan, Nigeria. West Afr. J. Med.18 (4):294-297.

[25] Salmon D, M Godlier, L Halle, P Lemonnier, JL Lorry, P Rouger, J Ruffie, C Salmon (1988). Blood groups in Papua NewGuinea Eastern Highlands, Gene Geogr. 2: 89 - 98.

[26] Srikumari, C.R., J, Rajanikumari.,\$ T.V. Rao.1987.Acuity of selective mechanisms operating on $\mathrm{ABO}$. $\mathrm{Rh}$ (D) and $\mathrm{MN}$ blood groups Am I phy anthrop 72(1): 117-121.

[27] Thangaraj K, CR Srikumari, A Ramesh (1992). The genetic composition of an endogenous Adi - Dravidar population ofTami - Nadu. Gene Geogr. 6: 27 - 30 .

[28] Yan, L., Zhu, F., Fu Q. and He J. (2005).ABO, Rh, MNS, Duffy, Kidd, Yt, scianna, and colton blood group systems in indigenous Chinese. Immunohematology, 21:10-14.

[29] Yousaf, M., Yousaf, N and Zahid, A. Pattern of ABOand Rh (D) blood groups distribution in BahawalpurDivision. Pak. J. Med. Res. 1988;27(1):40-41. 